技術資料

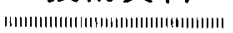

\title{
走査型放射温度計の高機能化
}

水野正志*, 八木富一*, 宇津野光朗 ${ }^{*}$, 矢野泰三*

\section{A New Radiation Thermometer of Linear Scanning Type with High Functions}

\author{
Masashi Mizuno, Tomikazu Yagi, Mitsuo Utsuno and Taizou Yano
}

\section{Synopsis}

A new radiation thermometer of linear scanning type which is convenient and has various functions is introduced in this report. These functions are realized by microcomputers.

The new major functions are following.

(1) Temperature distribution measurement.

(2) Selection of output type of measurement temperatures.

(3) Digital signal communication to external facilities. (ex. a personal computer)

(4) Proportion setting of usual output positions in a temperature distribution.

\section{1.はじめに}

鉄鋼の掣造をはじめ温度を取り扱ら各種業界に おいて，非接触測温手段としての放射温度計の需 要は年々増加してきている。た使用量の増加と ともに，钽小物体や振動物体あるいは幅広物体の 多点測温とバラェティに富んだ測温が要求される ようになってきている。大同特殊鋼秼（以下当社 といら)ではこれらの要求に答えるべく，1 次元 イメージンサを検出素子とした走査型放射温度 計を開発してきた。

しかし従来の走査型温度計では, マイコン処理 速度が遅いため， 1 次元的な放射エネルギ分布を 検出しながらす温度としての出力は 4 点（最高温 度 1 点十任意指定位置 3 点) だけであった。また 温度出力もノイズなどを含んだ測定値をそのまま

昭和63年 5 月 16 日 受付

*大同特殊鋼研究開発本部
出力するなど機能の低いものであった。 走查型放射温度計は，放射エネルギを検出して 電圧に変換する検出器と検出器からの電圧信号を 温度に変換して表示などをおこなら変換器とで構 成されるが，今回，変換器に分散型マイコンシス テムを採用することによって，温度分布の測定や 温度出力のモード化など機能向上させることがで きたのでここにその内容を報告する。

\section{2. イメージセンサによる温度測定}

イメージセンサを用いた温度測定の概要を第 1 図に示す。測定視野内にある湘定物体からの放射 エネルギ (赤外線) は, 温度計前面のレンズによ り集光されイメージセンサ上に結像する。イメー シセンサは放射エネルギ検出単位であるシリコン セル（受光面 $28 \mu \mathrm{m} \times 28 \mu \mathrm{m}$ ）が多数直線上に並ん だ形状をしており，個々のセルは結像面上の放射 エネルギに比例した出力電圧を発生する。したが ってセル出力電圧を順次走査し取り出すことによ 
り，直線上の放射エネルギ分布が検出できる。こ の放射エネルギ（セル出力電王）と温度とは式(1) に示す関係がある。したがって第1図の方法によ り直線上の温度分布が測定でさる。

$$
V=C \cdot \operatorname{EXP}\left(-\frac{C_{2}}{A T+B}\right)
$$

ただし， $V$ : セル出力電圧

$T$ : 測定物体温度 (絶対温度)

$C_{2}$ : 放射の第 2 定数 $\left(C_{2}=0.014388\right)$

$A ， B ， C$ : 検出波長などによって決 まる温度計固有の定数

(1)式によってセル出力電圧から測定物体の温度 を求めることを温度換算と呼び, これは精度向上 および換算時間短縮のため、マイコンを用いたテ ーブル方式で扰こなっている。

実際にイメージセンサを使用する場合には，七 ルごとに感度が異なっているため, 七ル感度補正 をおこな5必要がある。七ル感度のバラッキを測 定すると最大 $15 \%$ の゙ラッキがあった。したがっ

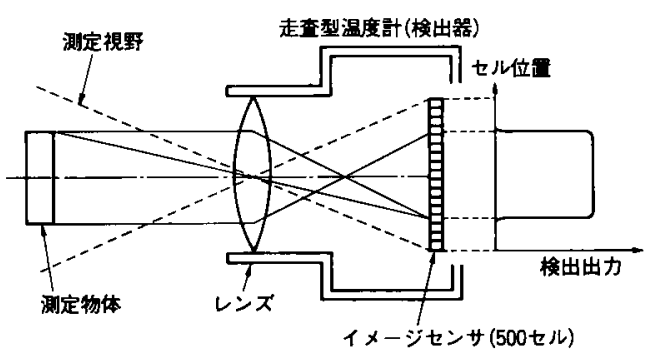

第 1 図イメーシヒンサによる温度測定
てあらかじめセル感度バラッキを測定しておき， オンライン測定時には500個のセルに対して次式 でセル感度補正を抗こなっている。

$$
V^{\prime}{ }_{1}=K_{1} \cdot V_{1}(\mathrm{i}=1-500)
$$

たたし $V^{\prime}$ ：補正後セル出力電王, $V_{1}$ : セル出 力電王, $K_{1}$ : 感度比補正俰数 $\left(K_{1} \geqq 1\right)$ である。 $K_{1}$ はハシラッキ測定時の最小セル感度を基準とす る。

以上述べてきたセル感度補正扣よび温度換算を 全セルに対して実施すると処理時間が長くなり, オンライン測定に適さなくなる。したがって従来 は, 最高温度と使用者が任意に指定した 3 点の位 置の計 4 点だけを温度出力していた。

\section{3. 分散型システム}

今回の改良にあたり，1）オンラインでの温度分 布, 測定を可能とする。2）精度を向上させるため マイコンで温度換算する。3）新機能を追加して使 い易すくする。の 3 点に重点を置き変換器の構成 を検討した。その結果，第 2 図に示すよらなマル チCPUシステムを採用し，並列処理によって全 体の処理速度を向上させ前記の 3 課題を満足する よう設計した。電子回路ではセル感度補正，CPU 1 では温度換算を主体とし最高温度検出・測定物 体幅検出など測定を分担, CPU 2 では温度分布測 定結果を基にして各種入出力制御を分担というよ

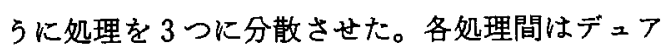
ルポートRAMによるバッフフ（電厈バッファ拉 よび温度ハッファ）を介してデータを伀達する。 デュアルポートRAMは両側のバスが独立して

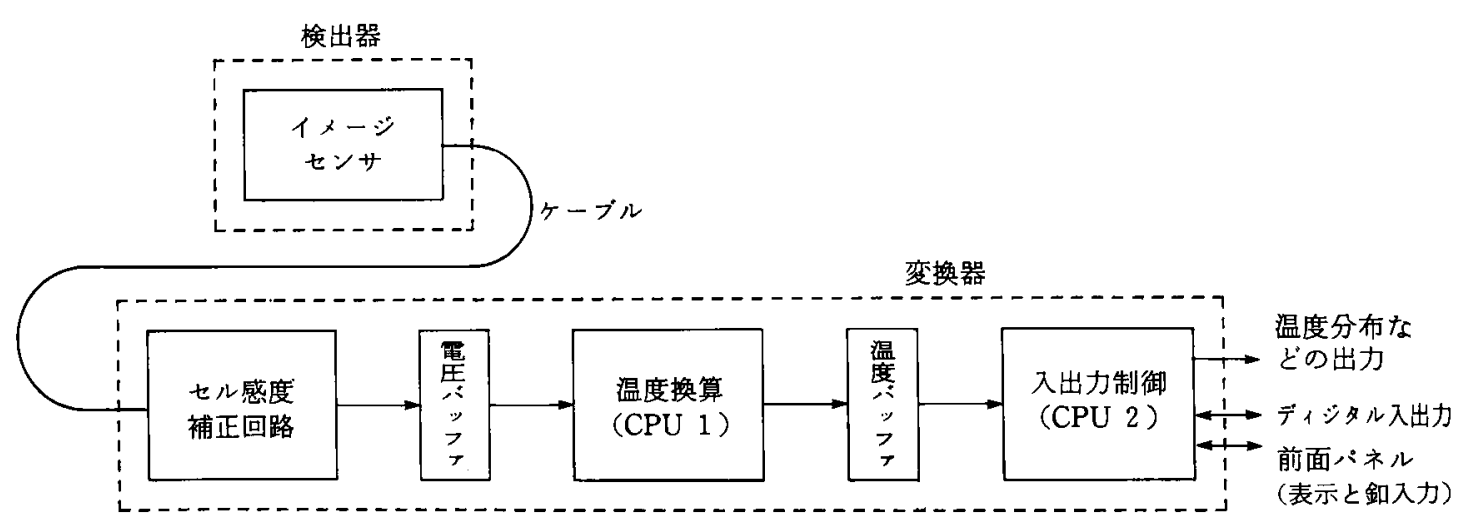


アクセスできるため, バス制御が簡単となると同 時にウェイト状態が生じず高速でフクセスできる 利点がある。

\section{4. 新 機 能}

分散型マイコンシステムを採用し，入出力制御 専用となったCPU 2 (第 2 図参照) は，上・下限 警報出力のよらな従来からの機能の他に，空き時 間を利用して種々の機能を追加させることができ た。以下に主な新機能を示す。

\section{1 温度分布出力機能}

今回の開発により温度分布が出力可能となった ため，温度分布測定の精度実験を括こなった。実 験方法は第 3 図に示すよ せる石コウボードに光を照射して測定面とし，こ れを走查型放射温度計で測定した。測定面は温度 差が生じるよ5に不均一な光強度分布とした。ま た走査型温度計のフォインダ内目盛位置 (測定視 野が10等分に目盛付けされている。)と同一部位を スポット型放射温度計で測定し基準温度とした。 スポット型温度計は，検出波長が走査型温度計と 同し $0.9 \mu \mathrm{m}$ 単波長であり, 測定面との距離・角度 を変えないよらに移動させて直線上の温度を11点 測定した。

実験結果は温度差士 $1{ }^{\circ} \mathrm{C}$ 以内と良好な測定精度 が得られた(第 4 図)。な招第 4 図で実線は走查型 温度計の測定值を示し, 丸印はスポット型温度計 で測定した温度基準値を示す。

\section{2 温度出力の多モード化}

測定した温度分布中の最高温度や指定した任意 位置（最大 3 点）の温度は, 温度分布出力とは別
端子から出力している。従来の走査型温度計はこ の温度出力を用いて記録計での記録や，制御装置 ヘ入力して温度管理を括こなっていた。しかし記 録結果の読み易さや制御装置側の制約などから, 時間平均やピークホールドなど, 測定值を加工し た出力がほしいといら要求が強かった。そこで第 1 表に示す各種モードを用意し, 使用者が自由に 選択できるよらにした。

また, 温度出力（フナログ出力）にスケーリン グ機能を追加した。従来の温度出力では, 測定温 度範囲を出カフルスパンに固定して対応させてい た。例えば LS-06 型 (旧型) の場合, 測定温度範 囲は600 1 100息であり, 電圧出力フルスパンは 0〜10Vであった。したがって温度出力值が $600^{\circ} \mathrm{C}, 850^{\circ} \mathrm{C}, 1100^{\circ} \mathrm{C}$ の場合, 電圧出力は各办

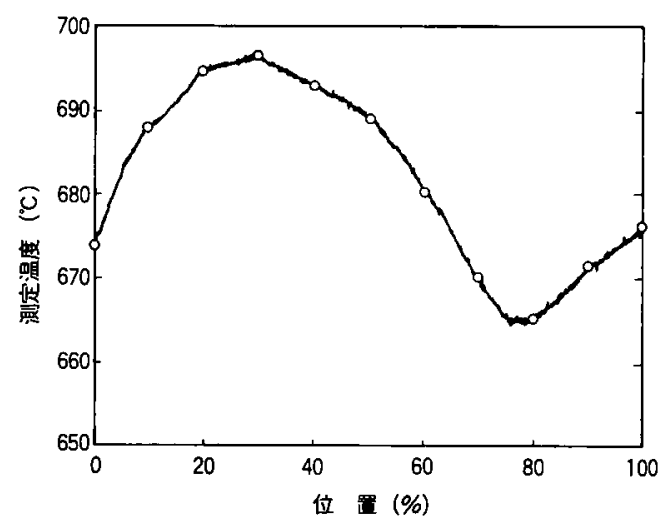

実線は走査型温度計で測定した温度分布を示す。 丸印はスポット型温度計で測定した基乷温度を示す。

第 4 図 温度分布測定結果

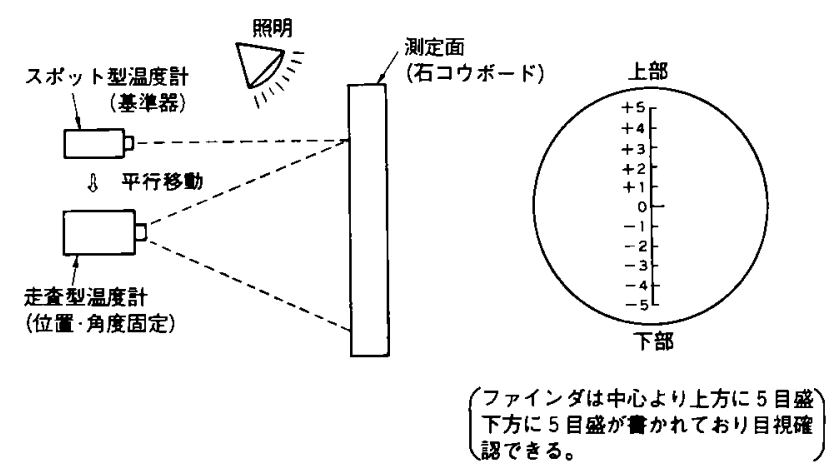

第 3 図 温度分布測定の精度実験方法 
第 1 表 温度出力モードの種類

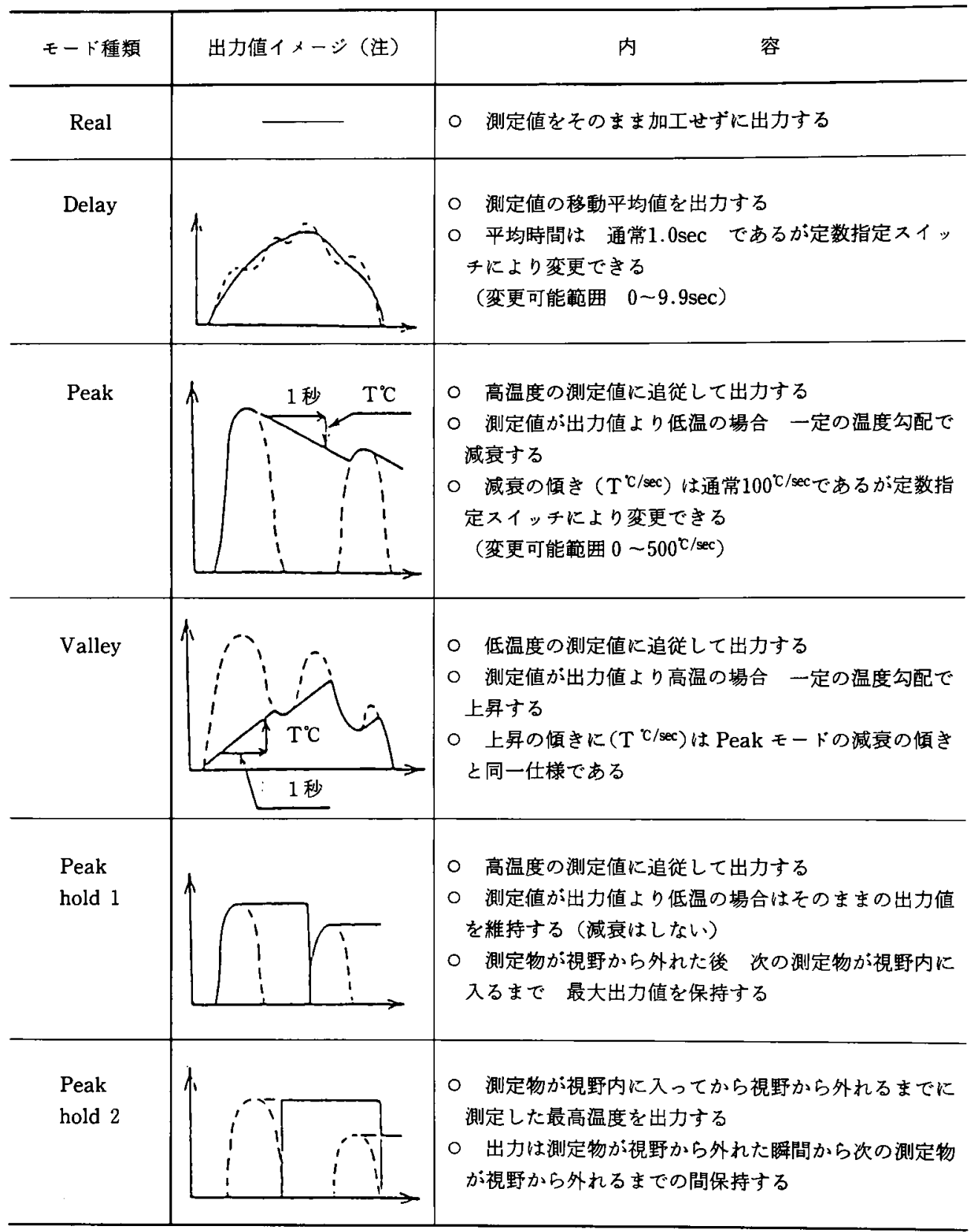

[注] 出カイメージ図中 縦軸: 温 度

横軸：経過時間 を示す 出力イメージ図中 点線：測定値

実線：温度出力値 を示す

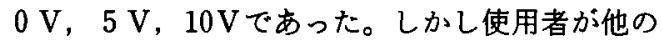
温度計を走查型温度計に置き換える場合や，测定 したい温度範囲が㹨い場合など，従来の記録計用 紙を継続して使用できない, 記録結果読取精度が 落ちる,などの問題があったため, 出力フルスパ
ン相当の温度出力下限值拉よび上限值を使用者が 任意に設定できるよらにした。これにより記録計 がより有効に利用できるよらになった。なお出力 電王値は(3)式で計算している。 
出力電压値 $=\frac{\text { 温度出力値 }- \text { 温度出力下限値 }}{\text { 温度出力上限値 }- \text { 温度出力下限値 }}$ $\times 10[\mathrm{~V}]$

たたし温度出力下限值・上限值は測定温度範囲 外には設定できない。

\section{3 位置指定の比率設定機能}

位置指定方法には，測定視野内での位置を指定 する絶対位置指定方法と, 測定物体端からの位置 を指定する相対位置指定方法とがある。相対位置 指定方法は測定視野に対して測定物体位置が大き く変動する場合に用いると便利である。従来は位 置指定をおこなう時, イメージセンサのセル数を 入力していた。しかしこの方法では，例えば測定 物体の中心を指定したい場合には，相対位置指定 方法で測定物体の端から中心までのセル数を入力 しなければならない。そこで測定視野幅と測定物 体幅との比率からセル数を計算していたが，直観 的に理解しにくかった。

今回, 使用者が\%比率値を入力すると，それを セル数に換算する機能を付加し，使い易すくした。 なお\%比率值は，絶対位置指定方法の時は全測定 視野を $100 \%$ とし，相対位置指定方法の時は測定物 体幅を $100 \%$ としている。測定物体幅は第 2 図に示
すCPU 1 が温度分布から常時測定している。前 述例の場合中心を指定したいから50\%と入力すれ ばよい。なお位置指定点数は従来と同様に最大 3 点までである。

\section{4 ディシタル入出力機能}

パソコンと接続して簡単にデータ収集ができる よらに，標準的通信方法である RS-232Cによる ディジタル入出力機能を追加した。

出力機能では, 最高温度および指定位置温度 ( 3 点）は常時出力し, 前面パネルの「ハターン」釦 を押すかディシタル入力で「パターン出力」コマ ンドが入力された時に, 温度分布（せル数分の温 度値，500データ)を出力する。これは温度分布出 力は情報量が多過ぎ，通信時間が長くなるため, 常時出力させられないことによる。

入力機能では, 温度分布出力指示や放射率など 各種定数の設定などのコマンド（指令）を設け, マイコンなど外部機器から自由に制御できるよう にした。

5. おわりに

分散型マイコンシステムを採用したことにより 種々の機能を追加し使い易い温度計ができた。同

第 2 表 走査型温度計（検出器）の主仕様

\begin{tabular}{|c|c|c|}
\hline 型 & $\mathrm{LS}-06$ & $\mathrm{LS}-08$ \\
\hline 測定温度範囲 & $600 \sim 1100^{\circ} \mathrm{C}$ & $800 \sim 1600^{\circ} \mathrm{C}$ \\
\hline 精度 $\left(\mathrm{Ta}=23^{\circ} \mathrm{C}\right)$ & 指示値の $\pm 1.0 \% \pm 1$ デシット $\left.{ }^{*} 1\right)$ & 指示值の $\pm 0.7 \% \pm 1$ デシッット(*1) \\
\hline 温度ドリフト & \multicolumn{2}{|l|}{ 指示値の $\pm 0.03 \% /{ }^{\circ} \mathrm{C}(* 1)$} \\
\hline 走査 速 度 & \multicolumn{2}{|l|}{$180 \mathrm{msec}$} \\
\hline 検 出 素子 & \multicolumn{2}{|l|}{ 一次元 MOS イメージセンサ（500画素） } \\
\hline 検出波長 & \multicolumn{2}{|l|}{$0.9 \mu \mathrm{m}$} \\
\hline 測 定 距 離 & \multicolumn{2}{|c|}{ 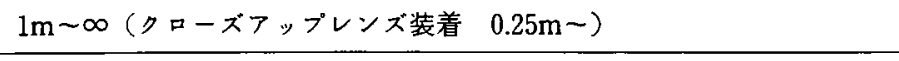 } \\
\hline 测 定 視 野 & \multicolumn{2}{|l|}{$11.4^{\circ}(200 \mathrm{~mm} / \mathrm{m})$} \\
\hline 位 置 分 解 能 & \multicolumn{2}{|c|}{$0.4 \mathrm{~mm} / \mathrm{m}$ (クローズフップレンズ装着 $0.1 \mathrm{~mm})$} \\
\hline 最小測 定 幅 & \multicolumn{2}{|l|}{$2.0 \mathrm{~mm} / \mathrm{m}$} \\
\hline ファインダ視野 & \multicolumn{2}{|l|}{$13.7^{\circ}$} \\
\hline 使用温度範囲 & \multicolumn{2}{|l|}{$0 \sim 50^{\circ} \mathrm{C}$} \\
\hline 接続ヶーブル & \multicolumn{2}{|l|}{ 専用ヶーブル使用で最大 $100 \mathrm{~m}$} \\
\hline 重 & \multicolumn{2}{|l|}{$2.5 \mathrm{~kg}$} \\
\hline
\end{tabular}

(*1) 放射率 $=1.0$ 
第 3 表 走查型温度計（変換器）の主仕様

\begin{tabular}{|c|c|}
\hline 式 & $\mathrm{LSP}-08$ \\
\hline 温 度 表 示 & ディジル 4 桁表示 (360msec 間隔) \\
\hline 放射率補正 & $1.00 \sim 0.10$ (0.01間隔) \\
\hline リ $=$ フライザ & ROM テープル方式 \\
\hline 位置指定方法 & 絶対位置指定または相対位置指定 \\
\hline 出 力 信 号 & $\begin{aligned} \text { アナロタ: } & \text { 電流 } 4 \sim 20 \mathrm{~mA} \text { または電压 } 0 \sim 10 \mathrm{~V} \\
& \text { (アインレート出力) } \\
& \text { 精度 } \pm 0.2 \% / \mathrm{F} . \mathrm{S} \\
& \text { ピーク温度 } 1 \text { 点 位置指定温度 } 3 \text { 点 同時出力 } \\
& \text { パターン出力 }(0 \sim 10 \mathrm{~V}) \\
& \text { ピーク温度位置出力 }(0 \sim 10 \mathrm{~V}) \\
\text { ディシタル } & \mathrm{RS}-232 \mathrm{C} \\
& \text { ピーク温度 } 1 \text { 点 位置指定温度 } 3 \text { 点 同時出力 } \\
& \\
& \end{aligned}$ \\
\hline 出力 間 隔 & $360 \mathrm{msec}$ ただしパターン出力時間（ディシタル）は7 $\mathrm{sec}$ 以上 \\
\hline 警 & $\begin{array}{l}\text { 上下限設定：ピーク温度 } 1 \text { 点または } \\
\text { 位置指定温度 } 3 \text { 点の内 } 1 \text { 点のみ選択設定可能 } \\
\text { 出 力 : 上下限外れの接点信号 材料有無の接点信号 }\end{array}$ \\
\hline 使 用 電 源 & $\mathrm{AC} 100 \sim 220 \mathrm{~V} \pm 10 \%(50 / 60 \mathrm{~Hz})$ \\
\hline 量 & $3.5 \mathrm{~kg}$ \\
\hline
\end{tabular}

時に徒来電子回路で実現していた機能もマイコン 化したことにより, 変換器の形状寸法がW $430 \times$ ${ }^{\mathrm{H}} 250 \times{ }^{\mathrm{L}} 450$ から ${ }^{\mathrm{W}} 144 \times{ }^{\mathrm{H}} 144 \times{ }^{\mathrm{L}} 333$ と非常に小型で コンパクトなものとなった。なお走査型放射温度
計の主仕様を第 2 表、第 3 表に示す。

今後は，測定視野角の広角化・狭角化など使い 易さをさらに追求していさたい。 